\title{
Structure, Size, and Dynamics of Three European Hare Populations in Southern Sweden
}

\author{
Bo FRYLESTAM
}

\begin{abstract}
Frylestam B., 1979: Structure, size, and dynamics of three European hare populations in Southern Sweden. Acta theriol., 24, 33: $449-464$ [With 4 Tables \& 2 Figs.].

Structure, size, and dynamics of three European hare, Lepus europaeus $\mathrm{Pa} 11 \mathrm{as}, 1778$ populations were studied in Southern Sweden during 1974 1976. Population densities were estimated in spring and autumn by the use of spotlights at night. Sex ratio and age structure were analysed on the basis of hunting bags. The sex ratio did not differ significantly from a 1:1 ratio, but females usually predominated in the samples. Age distribution and survival rates indicated a constant mortality of $50 \%$ in mainland areas, whereas in an island population, the observed survival rate differed significantly from the expected due to the dominance of juveniles in autumn. No hares older than five years were found, indicating a turn-over of the cohorts of 5-6 years. Average population density differed significantly between the areas. Highest densities were recorded in the island population and lowest in a pasture area. The reproduction rate was determined by fertility of females and adult survival rather than by the size of the spring population. The actual population growth from spring to autumn was determined by both juvenile and adult survival rates. In the island population juvenile mortality was related primarily to food scarcity in summer. Winter mortality, hunting excluded, was generally lower than summer mortality; hunting being mostly responsible for the total winter losses.

[Dept. Anim. Ecol., Ecology Building, S-223 62 Lund, Sweden]
\end{abstract}

\section{INTRODUCTION}

The European hare, Lepus europaeus P a 11 a s, 1778 was introduced into Southern Sweden at the end of the 1860s. It became well established and dispersed rapidly both spontaneously and by further introduction into the southern and middle parts of Sweden. Since the 1930s the distribution ranges over the whole country except for the northernmost part.

The hunting statistics of the Swedish Sportsmen's Association show a marked peak in numbers of hares shot at the beginning of the $1950 \mathrm{~s}$ (Frylestam, 1976a). Thereafter the hunting bag declined, from 124,000 hares in $1950 / 51$ to about 50,000 at the beginning of the 1970 s. Taking into consideration improved hunting efficiency and increased 
hunting pressure it seems probably that the statistics reflect a real decline in the hare population.

Declines in European hare populations are noted in several European countries and are mostly associated with changes in the species' habitat (P i e low s ki \& R a c z y ńs ki, 1976). A similar relation might account for the change in the Swedish hare population, drastic changes in agricultural practice having occurred since the Second World War. Effects of various human activities on hare populations have recently been documented in a number of papers (Pielow ski \& P ucek (ed.), 1976).

This study examined the structure, size, and dynamics of European hare populations in selected areas in relation to various environmental factors associated with different land utilization. For each area the central question was: what main factors limit the hare population?

\section{STUDY AREAS}

Three study areas were selected in the province of Skane: the island of Ven situated in the strait of Oresund between Sweden and Denmark, the estate of Vasatorp near the town Helsingborg in NW Scania, and the Revinge area $20 \mathrm{~km}$ east of Lund.

Table 1

Characterization of study areas. Occurrence or importance of some variables is indicated by a scale from one $(+)$ to three $(+++)$.

\begin{tabular}{|c|c|c|c|}
\hline & $\begin{array}{l}\text { Island } \\
\text { of Ven }\end{array}$ & Vasatorp & Revinge \\
\hline $\begin{array}{l}\text { Size of sampling area, ha } \\
\text { Main use of land }\end{array}$ & $\begin{array}{c}79 \\
\text { Agriculture }\end{array}$ & $\begin{array}{c}129 \\
\text { Agriculture }\end{array}$ & $\begin{array}{l}\text { Military training; } \\
\text { Mattle-grazing }\end{array}$ \\
\hline $\begin{array}{l}\text { Soil } \\
\text { Habitat diversity } \\
\text { Food conditions, winter } \\
\text { Food conditions, summer } \\
\text { Disturbances } \\
\text { Occurrence of predators } \\
\text { Road traffic }\end{array}$ & $\begin{array}{l}\text { Clay } \\
++ \\
++ \\
++ \\
++ \\
+ \\
+ \\
+\end{array}$ & $\begin{array}{l}\text { Clay loam } \\
+++ \\
+++ \\
+++ \\
+ \\
++ \\
+++\end{array}$ & $\begin{array}{l}\text { Sand } \\
+ \\
+ \\
++ \\
++ \\
++ \\
++ \\
++\end{array}$ \\
\hline
\end{tabular}

Table 1 gives a characterization of the areas. To simplify comparisons between the areas, the importance of various environmental factors is indicated with a gradation from one $(+)$ to three $(+++)$. The variables are defined as follows: $\mathrm{M}$ a in use of Land. Human use of land, typical for the area in question. $\mathrm{H}$ a bitat Diversity. Refers to variety of crops, green fields, field boundaries, and tree stands.

Food Conditions. Presence of suitable feeding grounds, and indicated for winter and summer. In the agricultural areas (Ven and Vasatorp) winter crops of mainly wheat, rape, and rye are grown from September to April/May. Apart from cultivated fields, there are only small areas of pasture, meadows, and 
copses of trees on the island of Ven. In the Vasatonp area, clover fields, extensive pastures, and golf-links replace grown crops as feeding grounds in summer and autumn (Frylestam, unpubl.). In the Revinge area, the pasture land is dominated by the grasses Dactylis glomerata and Agrostis tenuis. The soil is sandy; therefore the pasture is sensitive to drought. Furthermore, there is a drastic decline in biomass and quality of plants during winter (H ans s o n, 1971).

Disturbances. Refer to agriculture activities and human recreation.

Predators. Occurrence of predators is indicated both by species composition and a rough estimate on numbers. The island of Ven has no resident predators except the domestic cat, Felis catus and a sparse population of hooded crow, Corvus corone (J. Loman, i.c.). Resident and breeding predators common for both mainland areas are the following species: fox, Vulpes vulpes, polecat, Mustela putorius, stoat, M. erminea, domestic cat, Felis catus, kestrel, Falco tinnunculus, buzzard, Buteo buteo, tawny owl, Strix aluco and hooded crow, Corvus corone. The Revinge area also has: badger, Meles meles, mink, Mustela vison, weasel, M. nivalis, marsh harrier, Circus aeruginosus, long-eared owl, Asio otus. Winter visitors in all areas are as follows: goshawk, Accipiter gentilis, buzzard, Buteo buteo, rough-legged buzzard, Buteo lagopus and golden eagle, Aquila chrysaetos.

$\mathrm{Ro}$ ad $\mathrm{Tr}$ affic. A gradation of road traffic was made on the basis of road size and length.

\section{METHODS}

\subsection{Population Density}

With each study area, a number of sampling plots, 2 to 18 ha in size and representing different types of land use (distribution of crops and other field habitats), were selected (see Frylestam, 1976b). Table 1 lists the total area of these plots. The sampling plots were checked for hares from a car driven along a fixed route, and population densities were estimated by means of spotlight together with binoculars $(7 \times 50)$ at night between 2000 and $2300 \mathrm{~h}$ (F ry le s t a m, unpubl.). Being nocturnal, all hares were assumed to be active at this time (K a ł uziński \& Bresiński, 1976). Hares could be well observed at a distance of at most $300 \mathrm{~m}$. Counts were made on three to five occassions at the beginning of the breeding season (February/March) and the beginning of the hunting season (October/November) during $1974-1976$.

\subsection{Age Determination}

Eye lenses, mandibles, and reproductive data were collected from hares shot during the hunting season (October - December). The treatment of the eye lenses followed the recommendations by Andersen \& Jensen (1972). Two distinct fractions of lens weights, separated at $275 \mathrm{mg}$, made it possible to distinguish young of the year from adult hares. The age of hares older than one year was determined on the basis of periosteal growth lines in the mandible (Frylestam \& von Schantz, 1977).

\subsection{Reproduction Rate}

The annual reproduction rate was estimated on the basis of the number of reproductive females and the mean number of young born per female ( $\mathrm{Krebs}$, 
1972). Assuming a similar distributed monthly mortality of adult hares, it was calculated that females disappearing during the second part of the breeding season had participated in the reproduction during the first part of the season, thus half of the total number of females lost. Fertility was estimated on the basis of placental scars. The placental scars provide a reliable method for analysing the total number of young born of the year (Frylestam, unpubl.). Thus the reproduction rate was calculated as follows:

where:

$$
R R=N_{y}\left(N f_{1}-\frac{N f_{2}}{2}\right)
$$

$R R=$ Reproduction

$N_{y}=$ Mean No. of young born per female

$N f_{1}=$ No. of females in the spring population

$\mathrm{Nf}_{2}=$ No. of females lost during spring to autumn

\subsection{Mortality Rate}

Juvenile mortality was estimated as:

Total No. of young born - No. of juveniles in autumn;

Adult summer mortality as:

No. of hares in spring - No. of adults in autumn; and

Winter mortality (juveniles + adults) as:

No. of hares in autumn - No. of hares next spring.

Table 2

Sex ratio in samples from three European hare populations in Southern Sweden. NS=Not significant.

\begin{tabular}{lcrccc}
\hline Area & Year & $N$ & $\begin{array}{c}\text { Sex ratio } \\
\sigma^{*} \sigma^{*}: \text { \% }\end{array}$ & $\chi^{2}$ & $P$ \\
\hline Ven & 1974 & 88 & $1: 1.3$ & 1.64 & NS \\
& 1975 & 121 & $1: 1.3$ & 1.86 & NS \\
Vasatorp & 1976 & 50 & $1: 1.4$ & 1.28 & NS \\
& 1974 & 55 & $1: 1$ & 0.02 & NS \\
Revinge & 1975 & 70 & $1: 1.3$ & 1.42 & NS \\
& 1976 & 87 & $1: 1.4$ & 2.58 & NS \\
& 1974 & 89 & $1.6: 1^{*}$ & - & NS \\
& 1975 & 84 & $1: 1.4$ & 2.34 & NS \\
\hline
\end{tabular}

* Sex determinations unreliable.

Estimates of adult summer mortality and winter mortality assumed that there was no exchange of hares between the study areas and surrounding areas. But the estimates could be biassed by unbalanced movements of hares.

\section{RESULTS}

\subsection{Population Structure}

Sex r a ti o: No statistically significant differences from a $1: 1$ ratio were found, but females were consistently in excess in the samples 
obtained from the island of Ven and the Vasatorp area (Table 2). In the Revinge area, males dominated in 1976 and females in 1975. The

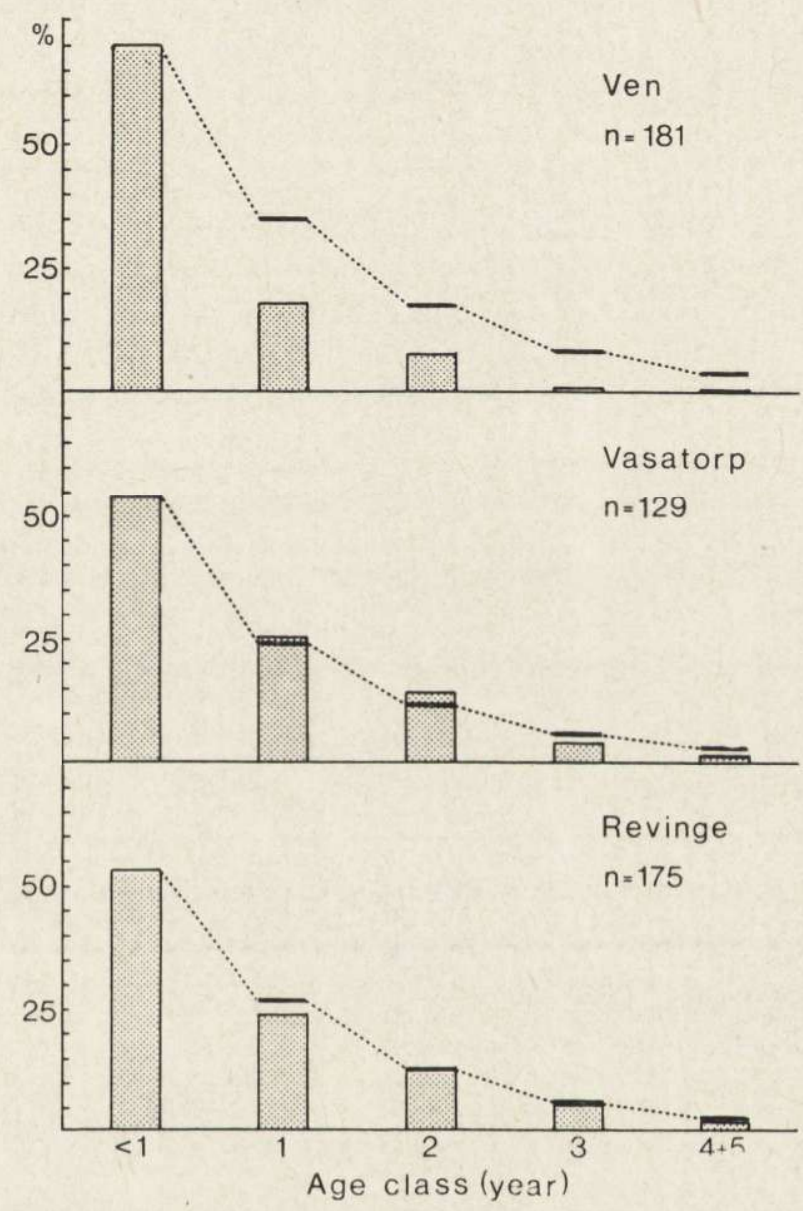

Fig. 1. Age distribution in three European hare populations in Southern Sweden, based on samples from 1975 and 1976.

Horizontal bars indicate the expected age distribution when assuming a constant mortality rate of $50 \%$. The observed distribution was tested against the expected distribution (Ven: $\chi^{2}=19.2, P<0.001$; Vasatorp: $\chi^{2}=1.30, P>0.05$; Revinge: $\chi^{2}=2.50$, $P>0.05)$.

highly biased ratio in 1974 is not reliable, as sex determinations failed in a part of the sample. The estimate of reproduction rate in this paper presumes a sex ratio of $1: 1$.

Age distribution: The age distribution of the examined populations did not differ significantly between the sampling years (1975 and 1976). Thus the age distribution is presented as the mean of the two samples from each area (Fig. 1). The actual age distribution was 
tested against a hypothetic population development based on a constant mortality rate of $50 \%$. The Vasatorp and Revinge populations showed no significant differences between the actual and expected age distribution (Fig. 1). The samples from the island of Ven showed a statistically significant difference. This was due to the predominance of juveniles of the year.

\subsection{Population Size and Dynamics}

Population densities in spring and autumn showed highly significant differences between the areas (Table 3). Differences between the Ven and Vasatorp populations were most pronounced in autumn.

\section{Table 3}

Population densities (hares/100 ha) in spring and autumn in three study areas in Southern Sweden as indicated by spotlight counts in sampling plots (see p.4). $+++=P<$ $0.001 ;++=P<0.01 ;+=P<0.05 ; \mathrm{NS}=$ Not significant. Twotailed $t$-test. Figures in parentheses are number of counts.

\begin{tabular}{lcccr}
\hline \multirow{2}{*}{ Area } & Year & Spring & Autumn & $P$ \\
\hline Ven & 1974 & $67 \pm 10.0(5)$ & $196 \pm 11.0(5)$ & +++ \\
& 1975 & $74 \pm 6.5(3)$ & $155 \pm 6.5(3)$ & +++ \\
Vasatorp & 1976 & $91 \pm 10.8(4)$ & $137 \pm 19.3(3)$ & ++ \\
& 1974 & $55 \pm 3.2(5)$ & $62 \pm 5.1(5)$ & + \\
& 1975 & $42 \pm 6.0(4)$ & $61 \pm 2.6(5)$ & +++ \\
Revinge & 1976 & $38 \pm 3.2(4)$ & $54 \pm 1.9(4)$ & +++ \\
& 1974 & $15 \pm 2.3(8)$ & $24 \pm 2.7(5)$ & +++ \\
& 1975 & $14 \pm 3.0(4)$ & $16 \pm 1.0(4)$ & $\mathrm{NS}$ \\
& 1976 & $14 \pm 2.4(6)$ & $16 \pm 2.2(4)$ & $\mathrm{NS}$ \\
\hline
\end{tabular}

Several factors determine the annual changes in hare numbers during the breeding season, i.e. (1) the number of reproductive females entering the breeding cycle, (2) mortality rate in breeding females, (3) reproduction success, (4) juvenile survival. Furthermore, winter mortality is included in the between-year population changes. These factors were analysed for each area.

I s l a nd of $\mathrm{V}$ e $\mathrm{n}$ : Population density in spring increased during the examined period (Table 4); between 1975 and 1976 the difference was statistically significant. The adult survival rate in 1975 was slightly higher than in 1974, but there was a decrease in average fertility by 1.2 young per female (Table 4). The young born in 1975 were therefore fewer than in 1974. The reproduction rate was about the same in 1975 and 1976 , as was the mean fertility. Thus, despite higher spring density 
in 1976, there was no corresponding rise in population size because adult mortality was higher than previously (Fig. 2).

Population density in autumn was primarily determined by the survival rate of juvenile hares (Fig. 2). In 1975, the juvenile mortality was high probably mainly due to disease, as indicated by hare carcasses found in spring and summer that year. The low juvenile survival rate resulted in a significant decline in autumn density (Table 4, Fig. 2). In 1976, the juvenile mortality was again high, as in 1975. In combination with low survival rate of adults, this means a continued decline in autumn density.

Most of the winter losses were caused by shooting at the end of November. The hunting bag in proportion to the autumn population was about the same in both winter seasons.

In $1975,57 \%$ of the calculated number of hares in autumn was shot. Only 67 hares per 100 ha in the following spring were left provided there was no other mortality. The spring density in 1976, estimated to 91 hares per 100 ha, could thus be reached only by an immigration of hares from the adjoining area where hunting pressure was lower and occurred later than in the study area. So the total loss in the study area in winter $1975 / 76$ was in fact higher than the calculated $41 \%$ (Table 4 ).

Vasatorp: The spring populations in this area slightly declined during the period (Table 4, Fig. 2), but the decrease was statistically significant only between the first two years. The adult summer mortality showed marked variations (Table 4). In 1974, the losses were exceptionally high. This was partly due to the construction of a new road, causing a temporary high traffic mortality. However, in 1975 the adult survival rate was high and the reproductive success slightly higher than the year before. In 1976, there was a drastic decline in the reproduction rate (Fig. 2) despite an increase in fertility (Table 4). This was due to the combined declines of spring density and adult survival rate.

The total winter losses were relatively constant in both seasons (Table 4), although in $1975 / 76$ there was a change in the ratio of shooting/other mortality compared with the previous season (Table 4).

R e vinge: The population density in spring varied little (Table 4). As the mean number of young born per female was practically the same every year (Table 4), the total number of young born and the autumn density were primarily determined by the adult survival rate. Due to this factor, there was hardly any population increase during the breeding seasons in 1975 and 1976 (Table 4. Fig. 2).

The winter losses in 1975/76 were much lower than in the previous winter season, whereas the hunting bag related to population density 


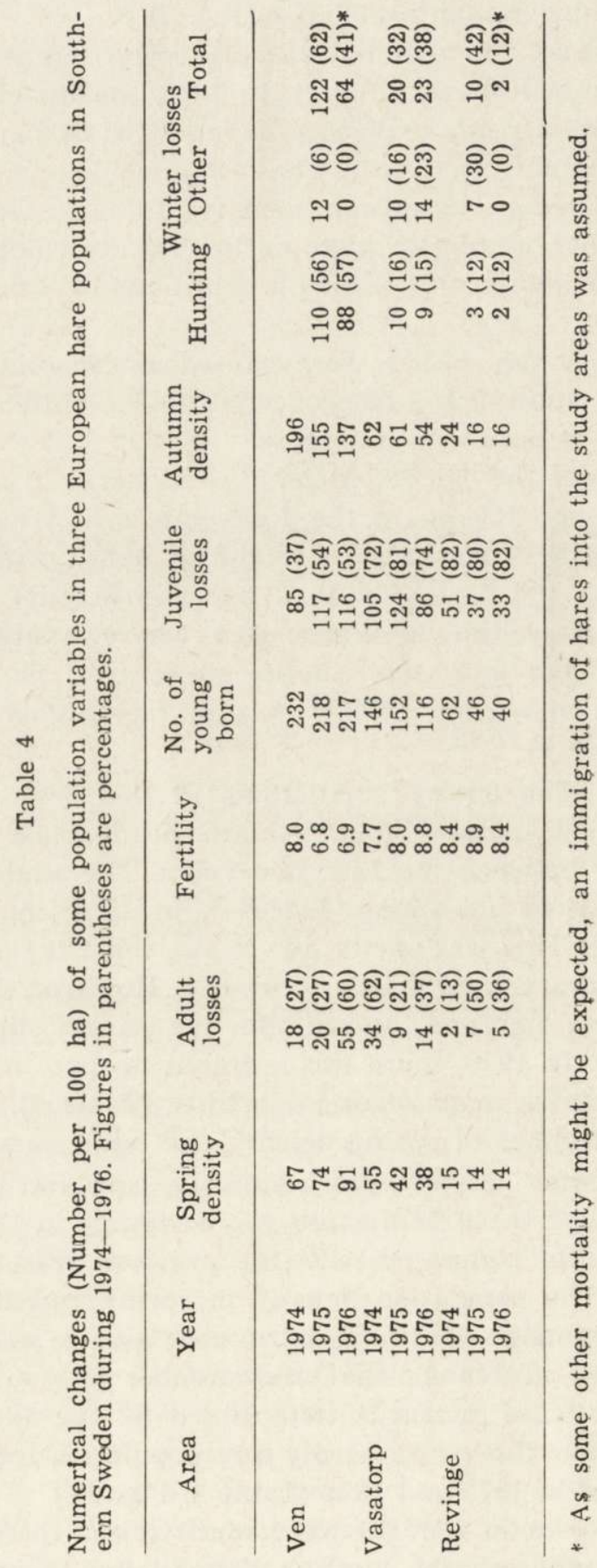




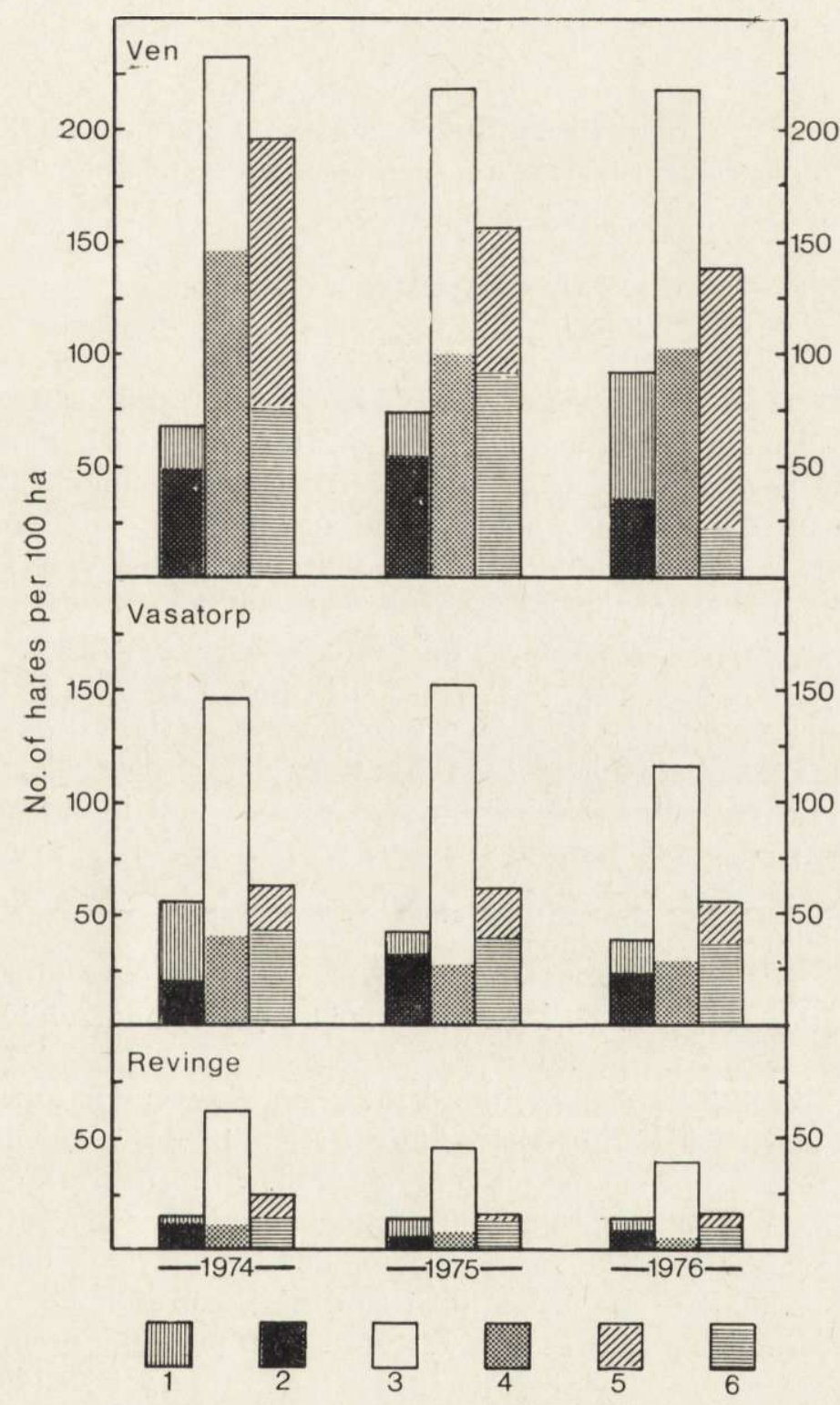

Fig. 2. Population dynamics of European hares in three study areas during 1974 to 1976.

Numerical changes in hare numbers are given as No. of individuals per 100 ha. (Presentation according to $\mathrm{R} \mathrm{a} \mathrm{c} \mathrm{z} \mathrm{y} \mathrm{ńs} \mathrm{k} \mathrm{i,} \mathrm{1974).}$

i. Adult mortality during spring-autumn, 2. Surviving adults in autumn, $1+2$. Spring population density, 3. Juvenile mortality during spring-autumn, 4. Surviving juveniles in autumn, $3+4$. Total number of young born, 5 . Winter mortality, 6. Number of hares surviving to the next spring, $5+6$. Autumn population density. 
was constant (Table 4). The decline in total winter losses was thus due to other mortality factors. In $1975 / 76$, all calculated losses were due to hunting. However, there might have been some other mortality; perhaps some immigration of hares occurred during the winter months, possibly from some favourable grazing areas bordering the neighbouring cultivated land.

\section{DISCUSSION}

\subsection{Sex Ratio}

Previous studies usually showed a small predominance of females in the hunting bags during the winter period ( $\mathrm{Pi}$ elow ski, 1969). However, in the hare population on the Danish island Illumö where over $90 \%$ of the total population was captured and marked, an overall dominance of males was recorded during autumn and winter ( $\mathrm{A} \mathrm{bil} \mathrm{d} \mathrm{g} \mathrm{a} \mathrm{r} d$ et al., 1972). In Poland, an average sex ratio in favour of males was found in foetuses throughout the breeding season ( $\mathrm{R} \mathrm{a} \mathrm{c} \mathrm{z} \mathrm{y} \mathrm{n} \mathrm{s} \mathrm{k} \mathrm{i,} \mathrm{1964).}$ As shown by Nováková \& Hanzl (1966), Pielowski (1969), Pielowski \& Raczynski (1976), the sex ratio of hares from the hunting bag might be biased by time of hunting and hunting methods. However, the variations in sex ration found in this study do not allow an analysis of possible sampling errors.

\subsection{Age Distribution and Survival}

Information on age distribution, survival, and turn-over in European hare populations is given by $\mathrm{P}$ e tr u s e w i c z (1970) and A b i l d gå r d et al. (1972)

When testing literature data, there is strong support for the assumption that a mortality rate of about $50 \%$ persists in European hare populations. There was generally an agreement with survival curves of type III of S lobodkin (1962), indicating a constant mortality when plotted on a log scale. The survival rates obtained at high densities in the Illumö population and from the island of Ven resemble the curve of type IV, showing highest mortality in the juvenile group. These findings support the statement made by Petrusewicz (1970) that no indications exist that the mortality rate should differ between different age classes of adult hares.

The turn-over of the studied populations was about five years. P e tr u. s e w i c z (1970) and A b il d gå r d et al. (1972) recorded up to seven generations during a seven-year-period, and the physiological longevity might be higher, as shown by Pielowski (1971). For the American black-tailed jackrabbit, Lepus c. californicus, a turn-over of five years 
was established (L e chleitner, 1959). The actual turn-over in the populations examined, however, could be somewhat longer than shown here because of under-representation of older hares in small samples.

In stable populations, the age distribution reflects the mortality rate, as actually. occurred in the samples examined here. However, the data presented by A b ild ga r d et al. (1972) showed that the age distribution differed from the expected distribution due to considerable variaions in recruitment of juveniles between years. For example, two-year old hares might be as abundant as one-year old hares when they originate from a year with high reproduction and a proportionally high number of survivals.

\subsection{Factors Affecting Population Size}

European hare populations vary much in size locally and regionally. In the Netherlands, the autumn populations usually number $50-60$ hares per 100 ha (Broeckhuizen, 1976), which is about the average density in good hare habitats (P i e low s k i \& R a c z y ńs k i, 1976). Population density figures reported from Poland are $10-50$ (P i e low sk i, 1976a), and from the German Democratic Republic 20-60 (M öller, 1967). Mostly, these variations are related to differences in habitat conditions and climate (Pielowski \& Raczyński, 1976).

The present study found considerable size differences between the populations.

Is land of Ven: Very high densities were noted in island populations of the European hare (A bild gå r et al., 1972) and the mountain hare, Lepus timidus (A ng e r b jörn, 1977). Concerning the Ven population, two main factors determined its size: dispersal, and reduced mortality rate.

Although restricted population estimates were made in part of the island only, it seems likely that the hare density prior the hunting season is about the same throughout the island. This means that habitats available to hares are occupied and the dispersal of mainly juvenile hares is practically inhibited. Furthermore, the sparse incidence of predators and inconsiderable road traffic might contribute to a higher survival in both juveniles and adults. Thus despite a comparatively lower mean fertility rate (Table 4) and a decline in food supply in summer (Table 1), high population densities are maintained.

V a s a torp: A high habitat diversity and balance in availability of feeding grounds throughout the year (Table 1) means that the food carrying capacity is higher than in the island of Ven. Despite this, the populations density was constantly lower than in the island (Table 4). This might be because factors negligible in the island most likely are 
important in regulating the size of this population. Apart from juvenile dispersal, mortality by predation (Goszczyński et al., 1976), agriculture disturbance ( $\mathrm{K}$ a ł u ziński \& Bresińs ki, 1976), and intense road traffic might play and decisive role in this case.

$\mathrm{R}$ evinge: The low densities recorded in the Revinge area (Tables 3 and 4) could be due mainly to the following factors: (1) food conditions, (2) disturbances, and (3) predation.

In the Revinge area, hares mainly use the extensive pastures for feeding. There is apparently no competition for food with domestic stock, but it was seen that the presence of cattle significantly affects the distribution of hares (Frylestam, 1976b). There is a large decrease in plant biomass and plant quality during winter, so food might be scarce. In summer there will be sufficient food for hares, but during the study period rainfall was scarce in the summer months, and the pastures were very dry. Possibly as a consequence of this, every year showed a decline in birth rate of young hares in July (Fryle$\mathrm{s} t$ a $\mathrm{m}$, unpubl.). Thus, it seems probable that the increased juvenile and adult mortality was partly due to poor food conditions. Similar efiects of low rainfall were observed in Nuttall's cottontail, Sylvilagus nut:allii (M c K a y \& V e r t s, 1978) and in the wild rabbit, Oryctolagus cunicalus, (M y e r s \& Gil b e r t, 1968). Summarized: food conditions in this area were apparently most important from the qualitative aspect.

Various disturbances are more widespread over the year than in the agricultural areas. Apart from grazing by cattle, human recreation and military training could be important during the breeding season. Possibly, reproductive females and still suckling juveniles are particularly vulnerable to such disturbances, but there are no data to support this. However, Nová k ová \& H a n zl (1966) found a negative relationship between hare reproduction and disturbances by human recreation.

The effect of predation on hares is still being analysed, but it was established that about $10 \%$ of the hares produced annually are predated by foxes (T. von S c h a n t z, l.c.).

\subsection{Factors Affecting Population Growth}

Data presented in Fig. 2 show that the annual increase in population is determined by: (1) fertility and (2) survival rate of adults and juveniles. A combined effect of these factors was especially pronounced in the island of Ven; a decrease in fertility and adult survival caused a decline in the number of young born. The increase in spring population density might also indicate a density-dependent reproduction. This is a common phenomenon which has been observed in several lagomorphs 
(A b i l d gå rd et al., 1972; F r e n ch et al., 1965; M e s low \& K e it h, 1968; N e w s o n, 1964). A significant inverse relation between fertility and population density was found when the three areas were compared (F r y l e s t a m, unpubl.). With support from data given by $\mathrm{P}$ i elowski (1968) and Raczynski (1974), it can be stated that the size of the spring population is of little importance for the population growth during spring to autumn. Perhaps a hard selection in winter due to high mortality leaves fewer but more healthy and fertile females for the following reproduction season.

The mortality in young of the year is usually as high as $70-80 \%$ (P i e lowski \& R a c z yński, 1976), and data obtained in may mainland areas agree. However, in the island population, juvenile mortality was much lower in all years (Table 4, Fig. 2). This is due to the already described inhibited dispersal and low mortality. None the less, there was an increase in juvenile mortality in 1975 and 1976. Apart from a period of possible disease in 1975, this increase could be due to food scarcity resulting from increased spring population density. The low body weights of adults recorded in island hares during the first two years, with high autumn densities (Frylest a m, unpubl.) and possible agonistic behaviour between foraging hares ( $\mathrm{L}$ in $\mathrm{d} l$ öf, 1978), support the suggestion of competition for food. W in d b e r g \& K e it h (1976) studied population responses to high artificial densities in snowshoe hare, Lepus americanus, populations. They observed that higher emigration and low juvenile survival could be related to food scarcity and not mainly to population density. No similar responses were recorded in dense population where supplementary food was provided. An experimental situation analogous to the Ven population was described by M yers \& P o o le (1963). They found that starvation was the main density-limiting factor in wild rabbit, Oryctolagus cuniculus, populations where emigration was prevented and no predators were present.

According to Pielowski (1976b), juvenile losses are proportional to the number of young born. However, my results and data given by $\mathrm{R}$ a c z y n ski (1974) show that this is not always the case. For instance, a high adult survival followed by an increase in the total number of young born does not necessarily result in higher juvenile survival and an increase in population size. This also illustrates that mortality factors act differently on juveniles than on adults.

Mortality in winter, hunting excluded, is usually considerably less than in summer (Pielowski, 1968; Raczynski, 1974), as was also observed in this study, although winter losses were comparatively higher in years with dense autumn populations. When there is no hunting, however, a much higher natural mortality might be expected. 


\section{CONCLUSIONS}

In the man-made landscape, the size of the hare populations is primarily determined by habitat conditions. In the mainly agricultural areas (Ven and Vasatorp), the occurrence in winter of green crops, chiefly wheat, rape, rye and clover fields, ensures a good food supply (Frylest a m, unpubl.). Moreover, disturbances in these areas occur periodically and at long intervals. Despite the drastic decline in the size of suitable feeding grounds in the island of Ven in summer, population densities are generally higher than in the Vasatorp area owing to lack of emigration and reduced mortality, mainly due to the almost complete absence of predators and of road traffic. In the island population, reproduction and survival was apparently density-dependent.

In the Revinge area, the comparatively low population densities were due to nutrient factors, i.e. low plant biomass and quality in winter and dry conditions in summer combined with extensive grazing by cattle and various human activities.

Acknowledgements: I thank Professor P. Brinck, Department of Animal Ecology, Mr O. Bennet, estate of Vasatorp, and Mr $\mathbb{K}$. Alm, Uranienborg Farm, Ven, for working facilities, $\mathrm{Mr} \mathrm{K}$. Holde, $\mathrm{Mr} \mathrm{R}$. Alm and my colleagues in the Wildlife Research Group for valuable field assistance throughout the years, Professor P. Brinck, Dr S. Erlinge, Dr R. Gerell, Dr N. C. Stenseth and Dr P. H. Enckell for helpful comments on the manuscript, and $\mathrm{Mr}$ W.F. Salisbury for correcting my English. The investigation was supported by grants from the National Swedish Environment Protection Board to R. Gerell and G. Göransson.

\section{REFERENCES}

1. A bildgård F., Andersen J. \& Barndorf-Nielsen O., 1972: The hare population (Lepus europaeus Pallas) of Illumö, Denmark. Danish Rev. Game Biol., 6: 1-32.

2. Andersen J. \& Jensen B., 1972: The weight of the eye lens in European hares of known age. Acta theriol., 17, 8: 87-92.

3. Angerbjörn A., 1977: En studie av en extremt tät population av skogshare (Lepus timidus) på en västkustö. Zool. Revy, 4: 119 130 .

4. Broeckhuizen S., 1976: The situation of hare populations in the Netherlands. [In: »Ecology and management of European hare populations", Eds. Z. Pielowski \& Z. Pucek]. Państw. Wyd. Roln. i Leśn.: 23-24. Warszawa.

5. French N. R., McBride R. \& Detmer J., 1965: Fertility and population density of the black-tailed jackrabbit. J. Wildl. Manage., 29, 1: 14-26.

6. Frylestam B., 1976a: The European hare in Sweden. [In: „Ecology and management of European hare populations«, Eds. Z. Pielowski \& Z. Pucek]. Państw. Wyd. Roln. i Leśn.: 33. Warszawa.

7. Frylestam B., 1976b: Effects of cattle-grazing and harvesting of hay on density and distribution of an European hare population. [In: "Ecology and management of European hare populations«, Eds. Z. Pielowski \& Z. Pucek]. Państw. Wyd. Roln. i Leśn: 199-203. 
8. Frylestam B. \& von Schantz T., 1977: Age determination of European hares based on periosteal growth lines. Mammal Review, 7, 3-4: 151-154.

9. Hanss on L., 1971: Habitat, food and population dynamics of field vole Microtus agrestis (L.) in South Sweden. Viltrevy, 8: 267-378.

10. Goszczyński J., Ryszkowski L. \& Truszkowski J., 1976: The role of the European hare in the diet of predators in cultivated field systems. [In: "Ecology and management of European hare populations «, Eds. Z. Pielowski \& Z. Pucek]. Państw. Wyd. Roln. i Leśn: 127-133. Warszawa.

11. Kaluziński J. \& Bresiński W., 1976: The effect of the European hare and Roe Deer populations on the yields of cultivated plants. [In: "Ecology and management of European hare populations", Eds. Z. Pielowski \& Z. Pucek]. Państw. Wyd. Roln. i Leśn: 247-253. Warszawa.

12. Kałuziński J. \& Pielowski Z., 1976: The effect of technical agricultural operations on the hare population. [In: "Ecology and management of European hare populations", Eds. Z. Pielowski \& Z. Pucek]. Państw. Wyd. Roln. i Leśn: 205-211. Warszawa.

13. Krebs C. J., 1972: Ecology: The experimental analysis of distribution and abundance. Harper \& Row, Publishers: 1-694. New York.

14. Lechleitner R. R., 1959: Sex ratio, age classes and reproduction of the black-tailed jackrabbit. J. Mammal., 40, 1: 63-81.

15. Lindiöf B., 1978: Aggressive dominance rank in relation to feeding by European hare. Viltrevy, 10, 6: 145-158.

16. $\mathrm{McKay}$ D. O. \& Verts B. J., 1978: Estimates of some attributes of a population of Nuttall's cottontails. J. Wildl. Manage., 42, 1: 159-168.

17. Meslow E. C. \& Keith L. B., 1968: Demographic parameters of a snowshoe hare population. J. Wildl. Manage., 32, 4: 812-834.

18. Myers K. \& Poole W. E., 1963: A study of the biology of the wild rabbit, Oryctolagus cuniculus (L) , in confined populations. V. Population dynamics. CSIRO Wildlife Res., 8: 166-203.

19. Myers K. \& Gilbert N., 1968: Determination of ages of wild rabbits in Australia. J. Wildl. Manage., 32, 4: 841-849.

20. Möller D., 1967: Der nutzbare Zuwachs des Hasen in Abhängigkeit von Regionalen Klimaunterschieden. Arch. Forstwes., 16, 6-9: 927-930.

21. News on J., 1964: Reproduction and prenatal mortality of snowshoe hares on Manlitoulin Island, Ontario. Can. J. Zool., 42: 987-1005.

22. Nováková E. \& Hanzl R., 1966: Přispěvek k populačni dynamice zajice polniho (Lepus europaeus Pall.). Lymx, 8: 28-42.

23. Petrusewicz K., 1970: Dynamics and production of the hare population in Poland. Acta theriol., 15, 26: 413-445.

24. Pielowski Z., 1968: Die Jahresbilanz einer Hasenpopulation in Polen. Beiträge zur Jagd- und Wildforschung VI. Tag.-ber. dt. Akad. Landwirtsch.Wiss. Berlin. Nr. 104: 129-137.

25. Pi elowski Z., 1969: Sex ratio and weights of hares in Poland. Acta theriol., 14, 8: $119-131$.

26. Pielowski Z., 1971: Length of life of the hare. Acta theriol., 16, 6: 89-94.

27. P i elowski Z., 1976a: On the present state and perspectives on the European hare breeding in Poland. [In: „Ecology and management of European hare populations«, Eds. Z. Pielowski \& Z. Pucek]. Państw. Wyd. Roln. i Leśn: 25-27. Warszawa. 
28. Pielowski Z., 1976b: Number of young born and dynamics of the Europeam hare population. [In: "Ecology and management of European hare populations «, Eds. Z. Pielowski \& Z. Pucek]. Państw. Wyd. Roln. i Leśn: 75-78. Warszawa.

29. Pielowski Z. \& Pucek Z., Eds. 1976: Ecology and management of Euro-pean hare populations. Państw. Wyd. Roln. i Leśn: 1-288. Warszawa.

30. Pielowski Z. \& Raczyński J., 1976: Ecological conditions and rationail management of hare populations. [In: »Ecology and management of Europeam hare populations«, Eds. Z Pielowski \& Z. Pucek]. Państw. Wyd. Roln. i Leśnı: 269-286. Warszawa.

31. R a c z yński J., 1964: Studies on the European hare. V. Reproduction. Actaa theriol., 9, 19: $305-352$.

32. R a c z yński J., 1974: Die Gestaltung der Bestandsgrösse der Hasenpopulation nach einem mehrjährigen Zyklus. Trans. XIth Intern. Congr. Game Bioll. Stockholm 1973: 187-190.

33. Slobodkin L. B., 1961: Growth and regulation of animal populationss. Holt, Reinhart \& Winstan: $1-184$, New York.

34. Windberg L. A. \& Keith L. B., 1976: Snowshoe hare population responsie to artificial high densities. J. Wildl. Manage. 57, 3: 523-553.

Accepted, May 15, 1979.

Bo FRYLESTAM

\section{STRUKTURA, WIELKOSC I DYNAMIKA TRZECH POPULACJI ZAJACCA SZARAKA W POEUDNIOWEJ SZWECJI}

\section{Streszozenie}

Badano strukturę, wielkość i dynamikę trzech populacji (Tabela 1) zająca szaraka (Lepus europaeus P a 11 as, 1778) w poludniowej Szwecji, w latach $1974-1976$. Zagęszczenie populacji oceniano wiosną i jesienią, nocą przy użyciu reflektorów. Stosunek plei i strukturę wiekową oceniano na podstawie wyników polowań. Stosunek płci nie odbiega istotnie od wskaźnika $1: 1$, choć samice $\mathrm{z}$ reguły przeważają w badanych próbach (Tabela 2). Struktura wiekowa i przeżywalność wskazują, że w populacjach lądowych śmiertelność wynosi około $50 \%$, a w populacji wyspowej różni się istotnie z uwagi na dominację młodych jesienią (Ryc. 1). Nie mnaleziono osobników w wieku ponad 5 lat, co wskazuje że turnover kohorty wynosi 5-6 lat. Istnieje duże zróżnicowanie średniego zagęszczenia na poszczególnych obszarach (Tabela 4), a najwyższe jest na wyspie, zaś najniższe na pastwiskach (Tabela 3). Wydaje się, że liczebność populacji zależy przede wszystkim od warunków środowiskowych, przy czym obszar o zróżnicowanym użytkowaniu rolniczym jest korzystniejszy niż tereny murawowe. Wysoka liczebność na wyspie wynika $z$ braku możliwości migracji i niskiej śmiertelności, co z kolei wynika z braku drapieżników i ruchu pojazdów. Tempo reprodukcji wyliczano ze rwskaźników rozrodczości samic i przeżywalności dorosłych, a nie z wielkości wiosennej populacji. Stwierdzono, że rzeczywisty wzrost populacji od wiosny do jesieni określa przeżywalność zarówno młodych jak i dorosłych zajęcy. Smiertelność zimą jest niższa jak latem, a redukcja liczebności w tym czasie powodowana jest głównie odstrzałem prowadzonym w tym okresie (Ryc. 2). 